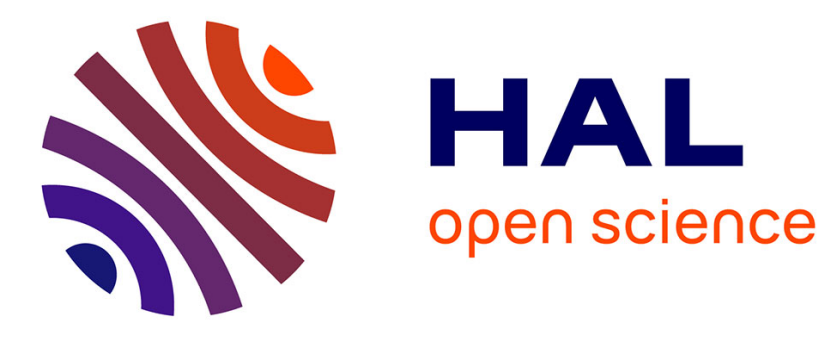

\title{
Pronominally marked noun determiners in Limbu
}

Boyd Michailovsky

\section{To cite this version:}

Boyd Michailovsky. Pronominally marked noun determiners in Limbu. Bielmeier, Roland; Haller, Felix. Linguistics of the Himalayas and beyond, 196, De Gruyter Mouton, pp.189-202, 2007, Trends in Linguistics. Studies and Monographs [TiLSM], 978-3-11-096899-6. halshs-00139592

\section{HAL Id: halshs-00139592 \\ https://shs.hal.science/halshs-00139592}

Submitted on 2 Apr 2007

HAL is a multi-disciplinary open access archive for the deposit and dissemination of scientific research documents, whether they are published or not. The documents may come from teaching and research institutions in France or abroad, or from public or private research centers.
L'archive ouverte pluridisciplinaire HAL, est destinée au dépôt et à la diffusion de documents scientifiques de niveau recherche, publiés ou non, émanant des établissements d'enseignement et de recherche français ou étrangers, des laboratoires publics ou privés. 
preprint from: Bielmeier, R. and F. Haller. in press. Himalayan Linguistics and Beyond.. Mouton.

\section{Pronominally marked noun determiners in Limbu}

Boyd Michailovsky

LACITO/CNRS Villejuif, France

\section{Introduction}

As in other Kiranti languages, nouns in Limbu are typically modified either by demonstratives, by pronominal prefixes, by other nouns (bearing the genitive suffix, but with a pronominal prefix on the head noun), or by propositions, participles, place-names, time-adverbs, etc., marked by the Limbu "nominalizing" suffix - $p a$. In a few cases, however, Limbu shows a different construction, in which the modifier bears a pronominal prefix, the $3 \mathrm{~d}$ singular "posessive" prefix $\mathrm{ku}$-. This type of determination is reflected in a common type of color-term derivative, e.g. kubhuitla 'pale'. The same prefix is found in a number of other words which typically function as modifiers or as predicate adjectives, like kuson 'new'. In compounds, a noun may take the place of the pronominal $k u$-, e.g. mikphuitla [“eye-pale”]

'European'. Similar phenomena are reported from other East Kiranti languages. ${ }^{1}$

\section{Modifier-Noun constructions}

I begin with a review of nominal modifiers in Limbu. Nominals may carry the definite suffix $-\varepsilon n$ or the plural suffix $-h a$ ?

\subsection{Demonstrative: DEM.-N (no marking)}

$$
\begin{aligned}
& \text { kha nese-'n (untimely209) } \\
& \text { that earring-DEF } \\
& \text { 'that earring' }
\end{aligned}
$$

\subsection{Genitive: (N-GEN)-PRON-N (head- and dependent-marking)}

The "possessed" head is marked by a pronominal prefix belonging to the paradigm $a$ - ' 1 st person', $k \varepsilon$ - ' $2 \mathrm{~d}$ person', $k u$ - ' $3 \mathrm{~d}$ person'. The genitive suffix on the dependent noun is $-r \varepsilon /-l \varepsilon$. Limbu independent pronouns do not take the genitive marker.

$$
\begin{array}{ll}
\text { ke-nn'ya-re } & \text { ku-him-mu (elope51) } \\
\text { 2-mat.aunt-GEN } & \text { 3-house-LOC } \\
\text { 'in your maternal aunt's house' }
\end{array}
$$

(3) $\quad y \varepsilon b a-' l l \varepsilon \quad k u-d h o k k-\varepsilon t m u$ (untimely138)

$$
\text { shaman-DEF.GEN 3-body-LOC }
$$

'into the body of the shaman'

(4) kha bakos-Elle ku-som-dhay (untimely271)

that box-DEF.GEN 3-top-LOC

'on (top of) that box'

\subsection{Relative clause, place-noun, time-adverb, etc.: X-pa N (dependent marking)}

The dependent-marker here is the "nominalizer" - $p a$, which in some contexts has a marked feminine -ma (cf. $p a$ 'father', ma 'mother'). The function of - $p a$ as a morphological element — the use which concerns us here - is to mark certain elements as nominal modifiers. Like other modifiers, these may serve as nominals in the absence of a head (see below). ${ }^{3}$

A time-adverb as modifier:

$\begin{array}{lll}\text { (5) } & \begin{array}{l}\text { asen- } b a \\ \text { before-NOM } \\ \text { 'old-timers' }\end{array} & \begin{array}{l}\text { khodakmi-re (dance125) } \\ \text { elder-ERG }\end{array}\end{array}$


A subject-relativization using the active participle:

(6) kha ke-si-bamona-n (untimely270)

that ACT-die-NOM man-DEF

'the dead man'

English adjectives are most often translated by Limbu "stative" verbs (whose aspectual character is more complex than their name suggests). Morphologically, these have an unprefixed participial form in place of the active participle of (6):

(7) yom-ba sara thik (trade143)

big-NOM boar one

'a big wild boar'

Any modifier, in the absence of an expressed head, can serve as a nominal; in other words, Limbu is a language in which 'big' may mean 'big one'.

(8) a-mba a-mma-re-'tmu (mariage39)

1-father 1-mother-GEN-LOC

'to/at my parents' [place]'

(9) kha ke-si-b'-en (untimely123)

that ACT-die-NOM-DEF

'the dead man'

\section{Color-words}

Color-words form a closed class in Limbu, with particular formal properties (cf. van Driem's "bound colour morphs" 1987:23-25). The following are found in the Mewa Khola dialect:

(10) het 'red'

hi:k 'yellow', 'green’ (Tembe, Phedap)

let 'raw, unripe, green, light "grue"”

mak 'black, dark'

om 'yellow'

phin 'blue, dark "grue"'

pho 'white'

phuit 'gray, pale'

Color-words appear in a number of constructions and characteristic derivations. They occur as predicates with the copulas $10^{\text {? } m a}$ 'to be like, to sound like, to make like...' and cokma 'to do, to behave':

(11) mak $b^{2}$ pekk-Elle bela (elope43)

black COP go-SUB time

'when it becomes dark'

(12) ma:kki let $10^{?}$

maize green COP

'the maize is green (unripe)'

These predicates can serve as modifiers, using the regular relative construction :

(13) om $k \varepsilon-1 o^{2}-b a \quad$ phuy

yellow ACT-COP-NOM flower

'yellow flower' 
There are a number of derived color-forms, some of them marked by the nominalizing suffix - $p a$ mentioned above. The morpheme - tan 'like' is used to form color adjectives of the form [COLOR]-tanba, e.g. maktanba 'black', phodanba 'white'.

Special suffixes -kongonba, -kokkokpa and $-y o^{2} y o^{2} b a$ are used to derive color adjectives expressing degrees of “[COLOR]ish”, e.g. makkongonba 'dark', phingokkokpa 'blueish', makyo 'yo 'ba 'blackish' (A).

But the most common and the most characteristic color-form has the prefix $\mathrm{ku}$ - and the otherwise unknown suffix -ra/-la, for example, kuhetla 'red', kubhora 'white':

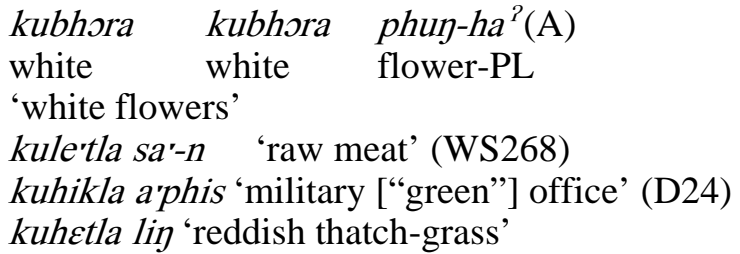

The prefix $k u$-is clearly the $3 \mathrm{~d}$ person clitic pronoun, although here it does not commute with the other clitic pronouns ( $a$ - ' 1 st person', $k \varepsilon$ - '2d person'). That is, if I am black, I am kumakla and not *a-makla. Note also that $\mathrm{ku}$ - marks the dependent modifier (i.e. the color) and not, as in the genitive construction, the head. ${ }^{4}$ Like other modifiers, the color-term can function as head:

kuhetla (thik) 'a red one', kuhetla-'n 'the red one'.

This is the construction that interests us here - or at least its lexicalized trace. Before discussing it further, I will present a few other lexical and morphological uses of $k u-.^{5}$

\section{Other pronominalized modifiers}

Three other words have the prefix $k u$-and the suffix -la, although they do not share other color-derivatives: kuls:pla 'cylindrical' (A) (cf. ls'ppet '[manner of] lying stretched out'), kugspla 'round' (A) (cf. kspma 'to surround, to reach around'), kusenla 'dried' (A) (cf. senma 'to dry in the air').

A small group of adjectives has the prefix $k u$-and the suffix -wet ( wa in Tembe): kuhinwet 'alive' (cf. himma 'to live'), kughonwet 'unripe (of fruits)', kumanwet 'uncooked', kusiwet 'dead' (cf. sima 'to die').

(18) Kusiwet sigbuy 'dead tree’ (A)

kumaywa sa 'raw meat' (Tembe dialect)

Further examples include the word 'new', which has the prefix $k u$ - with no suffix:

(19) Kuson him 'new house' (cf. sonma 'to sell')

kughekya sa 'dried meat' (cf. khekma 'to be dry').

Two pronominalized words express comparisons:

$$
\begin{aligned}
& \text { thi-n cwait kusiktanba cog-u } \\
& \text { beer-DEF water like make-30.pa } \\
& \text { 'he made the beer like water [i.e. weak]' }
\end{aligned}
$$

(21) a-mbhopa-si-re kusiktayba $\ldots$ colon hop (dance251)

1-uncle-COLL.GEN like $\quad . .$. custom not.exist

'there is no custom like that of my uncles' generation'

(22) jommo kudopba pot (dance62)

all same COP

'all [of our body-parts] are the same' 
In (22), kudonba is derived from the verb tonma 'to agree'. In (20), kusiktanba is related to the postposition kusik 'like, in the manner of', which generally has an adverbial sense. In both cases there is an extra argument, the comparandum, which could justify the pronominal ku-; note, however, that this argument is not in the genitive case.

\section{Modifier-compounds}

In compounds, these modifiers generally appear without the $k u$ - prefix, which can thus be seen as commuting with a compounded noun. There are two types of compounds: the first type occurs with color-words of the type kuhetla 'red', in which the pronominal element $k u$-may originally have indexed the head of a modifying construction. In compounds, what is logically a head-noun replaces the pronoun: structurally "meat-fresh" vs "its-fresh (meat)". Note that the usual modifier-head order of Limbu syntax is reversed:

$$
\begin{aligned}
& \text { saretla 'fresh meat' (cf. sa 'flesh') } \\
& \text { naghekya 'dried fish' (cf. pa 'fish') } \\
& \text { makkiretla 'green/unripe maize' (cf. ma:kki 'maize') } \\
& \text { thegek.hetla 'police (an Assam police force wearing red headgear)' (cf. thegek 'head') } \\
& \text { mikphu'tla (1) 'cataract', (2) 'European' [“pale-eye”] (cf. mik 'eye') }
\end{aligned}
$$

The second type also occurs with color words, and with 'new'. The pronominal prefix is again lost, but the usual order of determination is preserved: "black-earth" vs "its-black earth". (The identity of the compounded element is not always clear.)

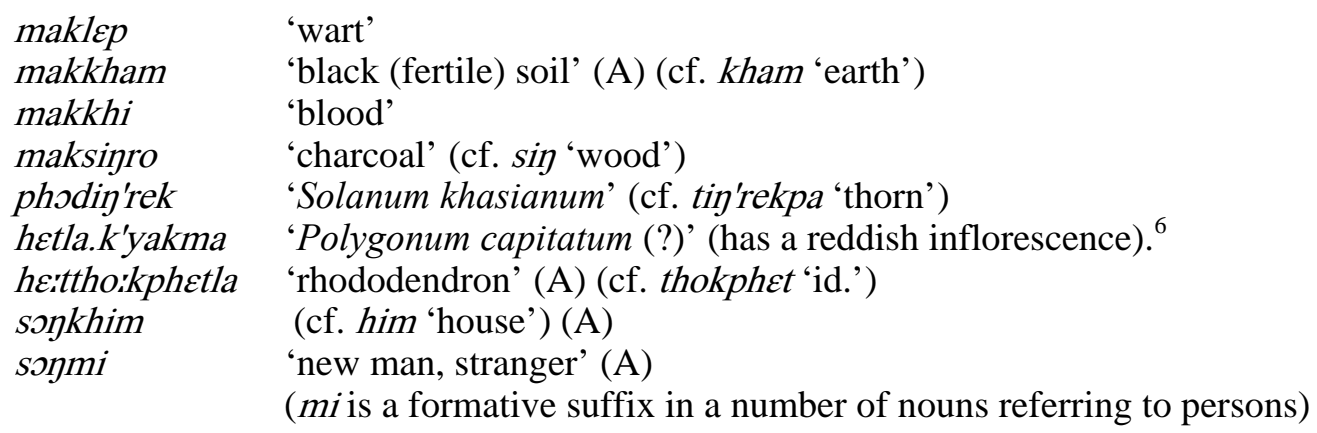

This is the order of modifier-head compounds generally in Limbu, with modifiers like cukpa 'small' which never take ku-, e.g. cukphe '(kind of) small knife' (A) (cf. phedza 'Nepalese knife').

\section{Relational nouns and compounds}

The great majority of $k u$-entries in the Academy dictionary are nouns, of which only a few will be cited here. Most have a relational sense, implying a relation to a whole, a source, a material, a complement, etc. In other words, to the extent that these words only appear with the pronominal prefix, they constitute a class of obligatorily possessed nouns. ${ }^{7}$ Grammatically, the prefix marks the head of a genitive expression, not a modifier as with color-words.

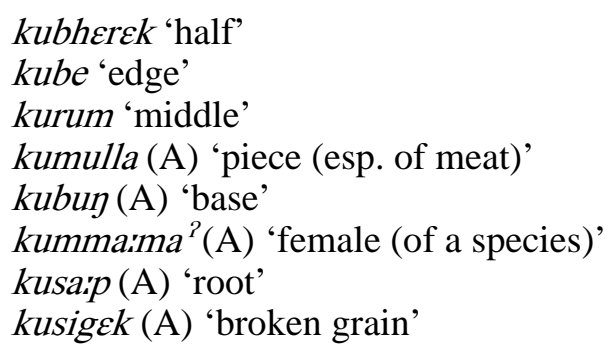

Many deverbal derivatives fall into this category, distinguished from the source verbs by the pronominal prefix. The prefixed form is either the present stem or the infinitive (suffix -ma). Note that the prefix $k u$-does not occur in the finite verbal paradigm (see appendix). 
(26)

\begin{tabular}{|c|c|}
\hline $\begin{array}{l}\text { Inam 'odor' } \\
\text { (in kunam nu/phen 'smells g }\end{array}$ & \\
\hline $\begin{array}{l}\text { kudza 'taste' } \\
\quad \text { (in kudza nu/phen 'is good/bad }\end{array}$ & $\begin{array}{l}\text { cama 'to eat' } \\
\text { sting') }\end{array}$ \\
\hline kusap 'decoration' & sapma 'to write' \\
\hline kudemn & temma 'to grasp' \\
\hline$k u d \varepsilon_{1}$ & tepma 'to cover'. \\
\hline e, place to stay & yanma (A) 'to put insi \\
\hline knife, etc & yumma 'to set, to fix' \\
\hline kue:p & epma 'to suppress' \\
\hline uge & kenm. \\
\hline
\end{tabular}

kughe:k 'piece' (A), 'odd member of a pair' khe:kma 'to have a nick, a missing tooth’

Relational nouns also enter into compounds. As in the case of modifier-compounds (above), a noun takes the place of the pronominal $k u$-. However, the semantic structure is different, because the noun that replaces the pronominal is logically a modifier and not the head: 'tree('s)-base' vs 'its-base'.
kudu:ppa 'large intestine (A)' hidut, hidurppa 'id.' (hi 'excrement')
kumulla (A) piece (esp. of meat) semulla 'piece of meat' (A) (? sa 'flesh')
kubup (A) 'base' phaksamulla 'a piece of pork' (phaksa 'pork')
kusa:p (A) 'root' sigbuy 'tree trunk' (A) (sin 'tree, wood')
kusigek (A) 'broken grain' sigsa:p 'tree-root' (A)
kuyun 'handle' ya ${ }^{2}$ sigek, ya ${ }^{2}$ sige:k (A) 'broken grain' ( $y a^{\text {? }}$ 'grain, rice') pheyug (A) 'knife-handle’ (phedza 'Nepalese knife’)

When the relational noun is itself the modifier, it comes first in the compound, e.g. in punsamman 'chief among hunting deities' (A) (cf. samman 'deity'), lumso:kma 'middle finger' (A) (cf. so:kma 'to point'). Where it is a quantifier, it can apparently come either before or after what is quantified, like NP quantifiers: phre:ydok ["half-pause”] 'semicolon' (A), togbhre:n [“year-half”] 'semester' (A).

\section{East Kiranti parallels}

The phenomena described above find an echo in Ebert's description of the closely-related language Athpare (1991:93-94) (Comments in square brackets are mine.):

Some adjectives [marked by the (singular) nominalizer -na] alternate with forms that have a prefix / $u-/[u-\sim o$, identical with the 3d person possessive prefix] and suffixes $-p a \sim-b a$ or -wat.

$\begin{array}{ll}\text { makna / umakpa } & \text { black } \\ \text { pinna / upinba } & \text { green } \\ \text { phana / uphaba } & \text { red } \\ \text { usikna / usikwat } & \text { dry }\end{array}$

[...]

The following adjectives are attested only with / $u-/$, although they have the ending -na (rather than -pa or -wat) or no suffix at all.
ucaphenna ugly, bad
[cf. Limbu kudza phen ("its-eating bad")]
ocetnuna
beautiful, nice
ohop empty
[cf. nu- 'become good']
uman raw
[cf. Limbu hopma 'not be, not exist']
[cf. Limbu kumanwet]

Ebert remarks (93n44):

The origin of the prefix / $u$-/ is obscure. It could be a frozen 3rd person possessive prefix, or the form $u--b a /-w a$ could be an old U[ndergoer]/S[ubject] participle. Cf. also

$\begin{array}{lll}\text { o-mok-pa } & \text { broth } & (<\text { mok-ma 'boil') } \\ \text { o-yan-wat } & \text { broken rice } & (<\text { yay-ma 'beat') } \\ \text { o-chon-wat } & \text { new } & (<\text { chon-ma 'sell' })^{8} \\ \text { u-pha-ba } \sim \text { u-pha-wa } & \text { money } & (<\text { ? })^{9}\end{array}$


Finally, from Bickel’s sketch of another East Kiranti language, Belhare (2003:563):

One adjective, uchoũat 'new', is attributed without further marking (uchoũat khim or khim uchoũat 'a/the new house') and appears to go back to a possessive construction meaning 'its-newness'. Such constructions are found with a few other concepts: e.g. natlabu u-son [banana 3POSS-ripe] 'the/a ripe banana'.

The post-nominal position of the adjective is not necessarily significant, since Belhare is described as head-final with a "post-phrase adjunct position". But if pronominally-marked adjectives are more frequent in this position than other attributes, it might be taken to reflect the headedness of the hypothesized "house its-newness".

\section{Burmese}

Bernot (1971) describes Burmese as a language without a specifically adjectival category, in which demonstratives, possessors, and relatives precede the head. Modifiers which would normally be translated by French or English adjectives are generally drawn from the category of "stative verbs", which can serve as predicates, be followed by modal particles, etc. (I omit consideration of Pali loans, used in the literary language.) These usually follow the noun. ${ }^{10} \mathrm{~A}$ few of them - essentially limited to color-words in the spoken language, although exceptional examples with 'new' and 'warm' are also cited - are marked by the prefix ? 2 -. Thus:

lu 'ci [ ’ji] 'adult [“man big”]'

'pan 'oni 'the red flower [“flower PFX-red"]'

The prefix in question also serves regularly to form deverbal nouns, as well as being found on a certain number of other nouns. Finally, it is lost in compounds, unless it is in first position.

Thus, as in Limbu, we have a nominalizing prefix which marks color-terms in their function as noun-modifiers. This is an interesting typological convergence, but perhaps no more than that. The Burmese prefix is not pronominal, at least not synchronically. The prefixed color-term, like other stative-verb modifiers in Burmese, usually follows the noun.

\section{Conclusion}

Pronominally-marked modifiers constitute a small, closed class in Limbu, consisting essentially of color terms and the word 'new' - among the usual suspects in closed classes of adjectives (Dixon 1994) — as well as 'living', 'dead', and a few others.

They are characterized by the presence of the pronominal prefix $\mathrm{ku}$ - The structure of the modifier, "its-[quality]", reflects grammaticalization of the notion that the quality is "possessed" by the noun. Syntactically, however, it seems clear that in an expression like kubhora phun 'white flower', 'flower' is the head, since head-final order is general in Limbu syntax. The pronominal morphology is frozen and unproductive.

The identification of the prefix as the $3 \mathrm{~d}$ person possessive pronoun is reinforced by the existence of compounds in which the pronoun commutes with a noun. A pronominal form like kuretla 'green, unripe' can be seen as representing any of the possible compounds saretla 'meat+fresh', ma:kkiretla 'maize+green/unripe', etc. Even in compounds where the internal order corresponds to the usual syntactic modifier-head order (e.g. phodin'rek 'white-thorn [Solanum khasianum]'), the prefix is almost always dropped (cf. note 6).

We might consider the prefixed adjectives like kuretla as simply grammaticalized pronominalizations derived from saretla, etc., but we would still have to explain the anomalous order of the latter, which falls out naturally from the "its-[quality]" grammaticalization path. Compounds with the more usual stative-verb-type modifiers — 'big' and 'little', for example — have only modifier-head order.

Pronominally marked modifiers are reported from two other East Kiranti languages, Athpare and Belhare. They have not been reported elsewhere in the Kiranti group. 
(WS) Weidert and Subba 1985 (Panchthar dialect); (D) van Driem 1987 (Phedap dialect). The transcription is IPA-based, except that $y$ is used for IPA [j] and $j$ for IPA [dz].

2. Examples from recorded texts are cited with references to the text and the sentence number. The texts (transcription, translation, and recorded sound) are available for browsing on the Lacito archive website: http://lacito.vjf.cnrs.fr.

3. This element also appears as a formative in a large number of nouns, not necessarily derived, designating persons or animals, e.g. keba 'tiger', thokpa 'weevil', yeba '(kind of) shaman', (feminine: yema), and in some others, e.g. nedejba 'cheek', including probable loans from Tibetan, e.g. thakpa 'rope', tonba '(kind of) drinking vessel'.

4. The Academy dictionary cites two examples of such forms with the nominalizer -pa, kumaklaba 'dark-complexioned man' and kumaklama 'dark-complexioned woman'. It is not clear whether these can occur as modifiers.

5. The precise status of the unaffixed color morphemes is somewhat ambivalent. Van Driem speaks of "bound colour morphs". This interpretation finds support in the form kuretla 'unripe', because, in the Mewa Khola at least, only dependent elements (suffixes, focus particles, verb stems in certain verbal expressions) show initial $r$ in postvocalic contexts (cf. van Driem 1990). Compare the independent noun lag 'leg', kulay 'his leg'. (This rule is apparently not observed in the standard Panchthar dialect, cf. kule tla in ex. 15 and in A, and kulay kuray, cited in A.) Syntactically, however, the color-words appear to be independent in exx. 11 and 12 .

6. Note that the suffix -ra is retained in this example, and in hetlaphun 'poinsettia' ["red-flower"] (A). The Academy dictionary also lists two compounds in which $k u$-is retained: kubhinlug 'sapphire' [“blue-stone”] (A), kuhE? lug 'ruby' [“red-stone”] (A) (cf. lug 'stone').

7. It is not clear to me that this is in fact the case. In my dictionary (2002) I have listed some of them as headwords without the prefix, and A lists most of them both with and without it. It is certain that both kin and body-part terms may appear unprefixed:

layn-elle tor-usige (father-in-law15)

foot-INST attack-1pl.ex. $\rightarrow 3$

'We two attacked it with [our] feet.'

8. I have applied Ebert's etymology for 'new' to Limbu kuson in (19) above.

9. Athpare 'money' is simply 'red', describing the copper coins that traditionally circulated in Nepal. Limbu money is $k \varepsilon$-sem-ba 'cold'.

10. Bernot argues that they are the heads of their NPs, and that the contradiction with the usual Burmese head-final order is only apparent. This question is not discussed here. 


\section{References:}

Asher, R. E. 1994 The Encyclopedia of Language and Linguistics. Oxford. Pergamon Press. Bernot, Denise. 1971 L'épithète en birman: contribution à l'étude des langues sans catégorie adjectivale. La Linguistique 7:1.41-53.

Bickel, Balthasar 2003 Belhare. Thurgood and LaPolla 2003:546-570.

Dixon, R. M. W. 1994 Adjectives. Asher 1994:1.29-34.

Driem, George van 1987 Limbu. Berlin. Mouton de Gruyter. [D]

Driem, George van 1990 The rise and fall of the phoneme / $\mathrm{r}$ / in eastern Kiranti: sound change in Tibeto-Burman. Bulletin of the School of Oriental and African Studies 53:1.83-86.

Ebert, Karen 1997 A Grammar of Athpare. München. Lincom Europa.

Michailovsky, Boyd 2002 Limbu-English Dictionary of the Mewa Khola dialect. Kathmandu. Mandala Book Point.

Royal Nepal Academy 2059 V.S. [2002] Limbu-Nepali-English Dictionary. Kathmandu. Royal Nepal Academy. (A). [Chief editor Bairagi Kainla.]

Thurgood, Graham, and Randy J. LaPolla 2003 The Sino-Tibetan Languages. London and New York. Routledge.

Weidert, Alfons and B. B. Subba 1985 Concise Limbu Grammar and Dictionary. Amsterdam. Lobster. [WS]

[An earlier version of this paper was presented at the 8th Himalayan Languages Symposium, Berne, 19-22 September 2002. The current preprint is from: in Bielmeier, R. and F. Haller, in press, Himalayan Linguistics and Beyond. Mouton.

The current preprint is available in the archive: http://halshs.archives-ouvertes.fr.

B.M. 3.04.2007]] 